\title{
Hybrid Abrasive Electrochemical Grinding Machining of alloy steel K110
}

\author{
Mohamed Hakima $^{\text {a }}$ Hossam. M. Yehia ${ }^{\mathrm{b}}$, Ahmed El-Assal ${ }^{\mathrm{c}}$, Khaled Abdelwahed ${ }^{\mathrm{b}}$

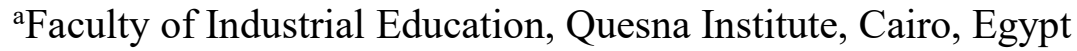 \\ ${ }^{b}$ Faculty of Industrial Education, Helwan University, Cairo, Egypt \\ ${ }^{b}$ Faculty of Engineering, Benha University, Cairo, Egypt \\ ${ }^{b}$ Faculty of Industrial Education, Helwan University, Cairo, Egypt
}

Corresponding author: - hossamelkeber@techedu.helwan.edu.eg, Tel. 02201008087742

\begin{abstract}
In this research, the effect of the $\mathrm{Al}_{2} \mathrm{O}_{3}$ abrasive particles on metal removal rate of the electrochemical grinding machining process was studied. All experimental works were performed at different voltages ( 9 and $11.5 \mathrm{~V})$, different feed rates $(6.74,13.63,22.55$ and, $27.44 \mathrm{Ipm})$, different electrolyte concentrations $(10,15$ and 20 wt. $\% \mathrm{NaCl})$, and different depths of cut $(0$ and $0.1 \mathrm{~mm})$. The abrasive particles powder weight percentages were varied from 2.5 to 7.5 . In order to study the effect of the abrasive particle powder, the results of the electrochemical grinding (ECG) were compared with the results of the abrasive electrochemical grinding (AECG). All experiments were performed for K110 alloy steel. The metal removal rate was determined by weighing the samples before and after machining, then dividing by the time of machining. Digital weight balance with $0.001 \mathrm{~g}$ accuracy was used. The results revealed that the metal removal rate increases by increasing the weight percentage of the $\mathrm{Al}_{2} \mathrm{O}_{3}$ abrasive particles up to $5 \mathrm{wt} \%$ then decreases. In addition, the effect of the abrasive particles was decreased by increasing the feed rate, salt electrolyte concentration and decreasing the depth of cut. The results of the electrical current show that the electrical current decreases at a percentage more than $5 \mathrm{wt} . \% \mathrm{Al}_{2} \mathrm{O}_{3}$.
\end{abstract}

Keywords: Hybrid electrochemical grinding; $\mathrm{Al}_{2} \mathrm{O}_{3}$ abrasive; Metal removal rate (MRR); Feed rate; Electrolyte concentration; Depth of cut. 


\section{Introduction}

The electrochemical grinding machining process is a process, which combines the electrochemical and mechanical action to remove the metal from the surface of the work-piece. Typically $90 \%$ of the metal is removed by the electrochemical action and $10 \%$ by the mechanical abrasive grinding wheel. In this process, the work-piece is connected to the positive electrode and the conductive grinding wheel is connected to the negative electrode. The electrolyte is usually a mixture of $\mathrm{NaNO}_{3}$ or $\mathrm{NaCl}$ salt dissolved in water. It is extensively utilized for machining of cutting tools, medical components, automotive and aerospace components due to its advantages, such as the absence of thermal damage, good surface finish, high metal removal rate, and long wheel life $[1,2]$.

In the electrochemical grinding machining process, especially at high voltages $(8-12 \mathrm{~V})$, some residual oxides on the work piece surface is produced during the machining process and this affects the metal removal rate, by preventing the reaction to take place with high efficiency. Also, it makes the surface of the workpiece dull.

Enhancing the efficiency of metal removal rate of the machining processes can be achieved by applying different cutting action on the material being machined. In particular, the electrochemical-mechanical action, which is used in the electrochemical grinding material removal process can be combined with respective mechanical interaction applied in another unconventional manufacturing processes such as ultrasonic machining (USM), abrasive jet machining (AJM), abrasive water jet machining (AWJM), abrasive electrochemical machining (AECM), and abrasive flow machining (ABFM).

Metal reinforced ceramic materials such as $\mathrm{Al}_{-}-\mathrm{Al}_{2} \mathrm{O}_{3}, \mathrm{Al}-\mathrm{SiC}, \mathrm{Al}-\mathrm{B}_{4} \mathrm{C}$, and WC-Co groups are not suitable to machine by the electrochemical (ECM) and electrochemical grinding (ECG) machining process for two reasons. The first is that materials are non-conductive while the second is that they are very hard [2-7]

Recently, more interests have been focused on increasing the material removal rate, and improving the machining accuracy. K. Rajkumar, et al have studied the effect of using $\mathrm{SiC}$ of $50 \mu \mathrm{m}$ particle size as abrasive in the abrasive assisted electrochemical machining process, and showed that abrasive assisted electrolyte aids in removing the precipitates, which gets formed during the electrochemical machining specially at high voltages. It also removes the burrs from the machining surface, which results in good surface finish. S.DAS, et al [4], have investigated the effect of different Boron Carbide abrasive grain diameters of $(16 \mu \mathrm{m}, 24 \mu \mathrm{m}, 34 \mu \mathrm{m}$, $44 \mu \mathrm{m}$ and $63 \mu \mathrm{m})$ and abrasive slurry concentration of $(50 \mathrm{~g} / 1$ and $60 \mathrm{~g} / \mathrm{l})$ on the metal removal rate of the USM. The results showed that the metal removal rate increases as the abrasive grain diameters and concentration increase.

$\mathrm{Al}_{2} \mathrm{O}_{3}, \mathrm{SiC}, \mathrm{B} 4 \mathrm{C}$, and diamond are the common used ceramic abrasive in the ultrasonic machining process [8]. Alumina as an advanced ceramic material is advantage with high hardness, corrosion resistance with chemical stability, and low 
density material. These properties make it an ideal material to perform in a variety of applications including alumina-based wearing parts, biomaterials and armors [9].

This research aims at studying the effect of $\mathrm{Al}_{2} \mathrm{O}_{3}$ abrasive powder as an assist abrasive for the electrochemical gridding machining process on the metal removal rate at different voltages, feed speeds, depths of cut, and different salt electrolyte concentrations. On the other hand, solving the problem of machining new composites materials, which contain non-conductive materials and difficult to machine by the ECG process, such as $\mathrm{Al}-\mathrm{SiC}$ and $\mathrm{Al}-\mathrm{Al}_{2} \mathrm{O}_{3}$.

\section{Experimental work}

\subsection{Materials}

Alumina powder of 2-3 $\mu \mathrm{m}$ particle size and density of $3.4 \mathrm{~g} / \mathrm{cm}^{3}$, which purchased from "Zircar Co. LTD" USA was used as an abrasive particles. Figures 1 and 2 show the $\mathrm{Al}_{2} \mathrm{O}_{3}$ powder and $\mathrm{X}$-ray diffraction of the $\mathrm{Al}_{2} \mathrm{O}_{3}$. It is shown from the $\mathrm{X}$-ray that $\mathrm{Al}_{2} \mathrm{O}_{3}$ has a cubic crystalline structure.

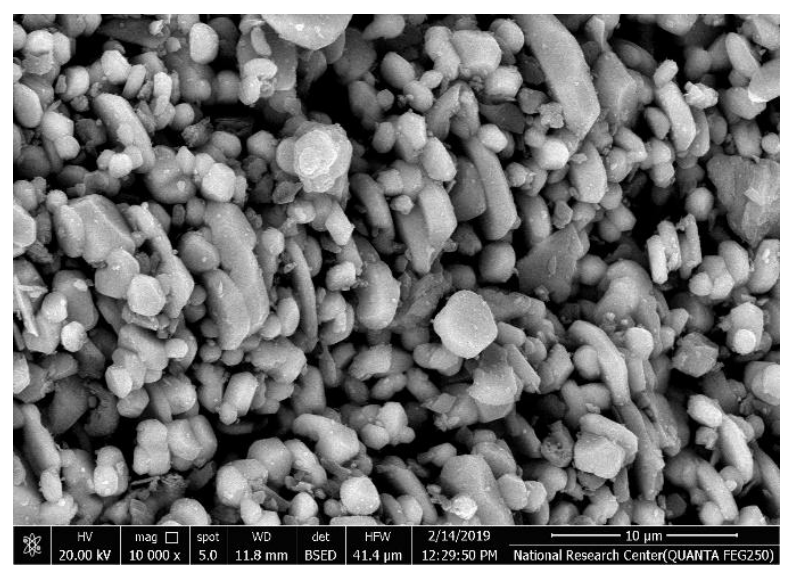

Fig. $1 \mathrm{Al}_{2} \mathrm{O}_{3}$ powder

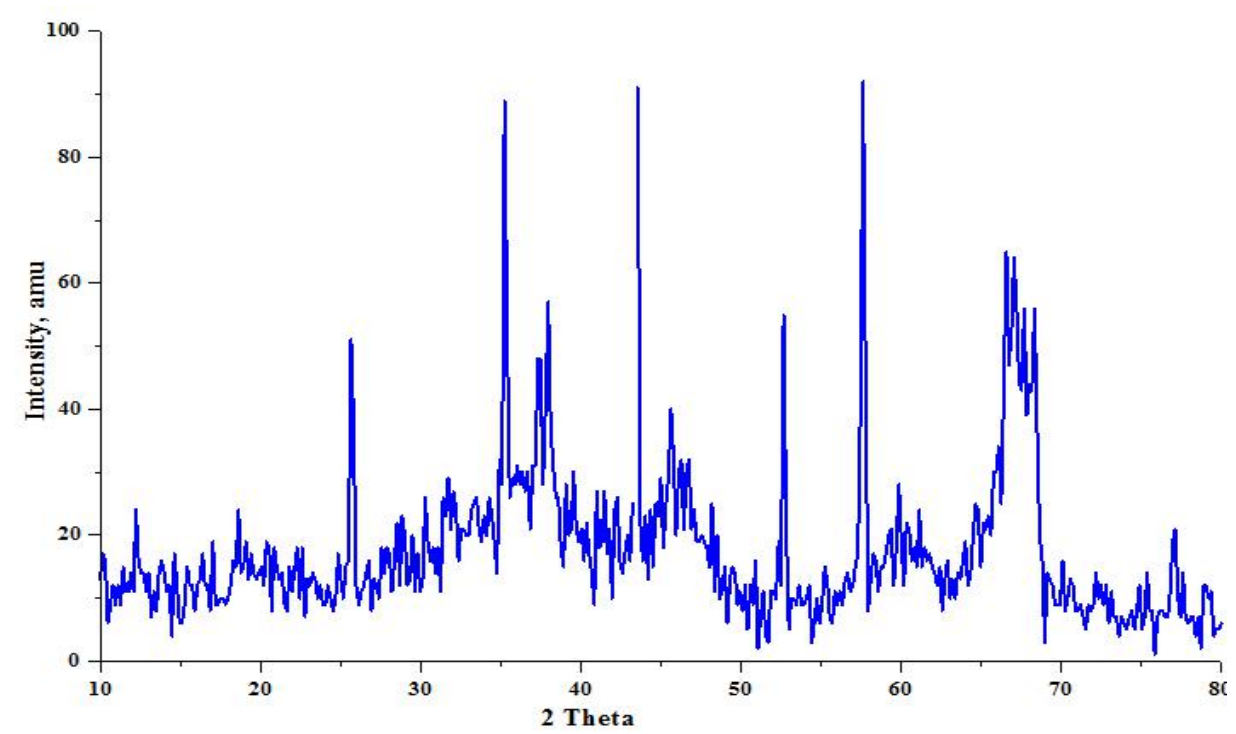

Fig. 2 X-Ray diffraction of alumina powder 
Sodium chloride ( $\mathrm{NaCl}$ salt) was used as the source of cations (positivelycharged ions) and anions (negatively-charged ions) of the electrolyte.

K110 alloy steel sample of $20 \mathrm{~mm}$ thick, $40 \mathrm{~mm}$ long, and $30 \mathrm{~mm}$ wide was used as work-piece material. The chemical composition of the used material is shown in table 1 . How did you get the composition?

Table 1: Chemical composition of K110 alloy steel

\begin{tabular}{|c|c|c|c|c|c|c|c|}
\hline Element & $\mathrm{C}$ & $\mathrm{Si}$ & $\mathrm{Mn}$ & $\mathrm{Cr}$ & $\mathrm{Mo}$ & $\mathrm{Ni}$ & $\mathrm{Fe}$ \\
\hline wt. \% & 0.38 & 0.30 & 1.50 & 2.00 & 0.20 & 1.10 & 94.52 \\
\hline
\end{tabular}

\subsection{Abrasive Electrochemical Grinding Test Rig}

All tests were run on an Everite ECG 618 Electrochemical surface grinder fitted with a 300 A.D.C power source and control panel consists of indicators showing current, voltage, and feed speed. A $3.73 \mathrm{KW} \mathrm{(5} \mathrm{hp)} \mathrm{motor} \mathrm{is} \mathrm{utilized} \mathrm{to} \mathrm{drive} \mathrm{the}$ spindle. The main parts of the abrasive assisted ECG machine are abrasive electrolyte tank, electrolytic Pump, cathode wheel, direct current power supply, and mechanical operation system, which includes cross feed positioning, and manual table movement. Figure 3 shows the experimental test rig of the abrasive assisted electrochemical grinding machining process. To make the powder of the $\mathrm{Al}_{2} \mathrm{O}_{3}$ suspend in the electrolyte during the machining process, a suitable electrolyte tank design was used to allow the vanes of the pump to perform this process.

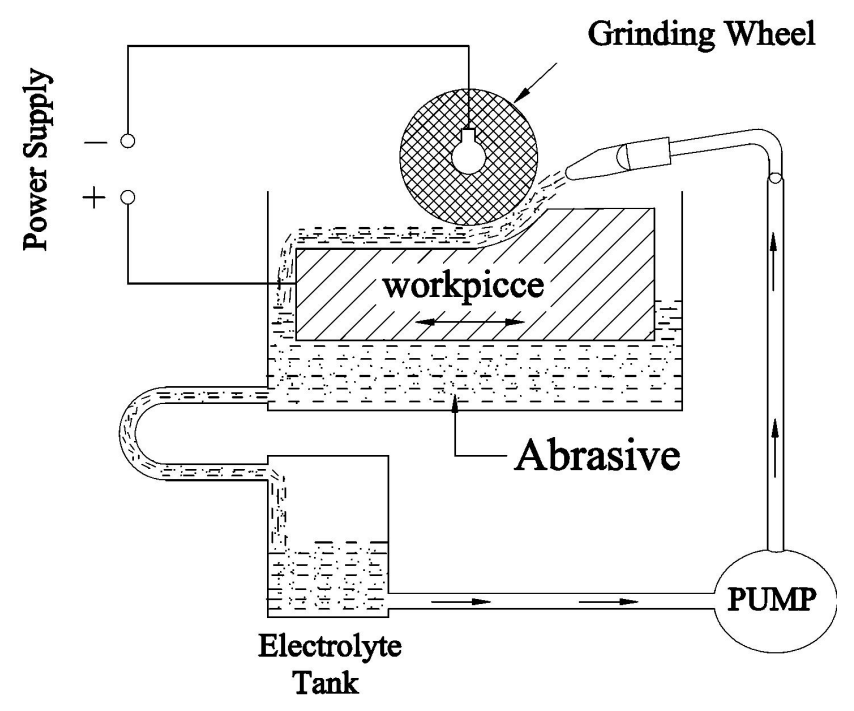

Fig. 3 Schematic diagram of the A-ECG

\subsection{Parameters of the study (Test Conditions)}

As it is shown in table (2), $\mathrm{Al}_{2} \mathrm{O}_{3}$ Abrasive particles concentrations, depths of cut, electrolyte flow rates, salt concentrations and the voltages were the main parameters of this study. 
Table 2: AECG process parameters and their levels

\begin{tabular}{|c|c|c|}
\hline parameter & values & Unit \\
\hline Abrasive concentration & $2.5,5$ and $7.5 \mathrm{wt} . \% \mathrm{Al}_{2} \mathrm{O}_{3}$ & $\mathrm{~g}$ \\
\hline Depth of cut & 0 (no depth of cut) and 0.1 & $\mathrm{~mm}$ \\
\hline Electrolyte flow rate & 2 & $1 / \mathrm{min}$ \\
\hline $\mathrm{NaCl}$ concentration & 10,15, and $20 \mathrm{wt} \% \mathrm{NaCl}$ & $\mathrm{g}$. \\
\hline Voltage (v) & 9 and 11.5 & Volt \\
\hline Feed rate (f) & $6.74,13.63,22.55$ and 27.44 & $\mathrm{Ipm}$ \\
\hline
\end{tabular}

Based on the weight loss, the metal removal rate (MRR) is calculated by using the following equation:

$$
\begin{gathered}
\text { cutting time }=\frac{\text { Lenth of the cuttig }}{\text { table feed rate }}, \mathrm{min} \\
M R R=\frac{\text { weight befor cutting }- \text { weight after cuttig }}{\text { cutting time }}, \mathrm{g} / \mathrm{min}
\end{gathered}
$$

\section{Results and discussion}

\subsection{Metal Removal Rate of the Electrochemical Grinding Process (ECG)}

Figure (4) shows the relationship between the feed rate and the metal removal rate of the electrochemical grinding machining process at $(0$ and $0.1 \mathrm{~mm})$ depth of cut and $(10,15$, and 20 wt. $\% \mathrm{NaCl})$ electrolyte concentration. All the experiments were performed at voltage $\mathrm{v}=9 \mathrm{~V}$. It is clear that the MRR increases as the feed rate increases. Also, the MRR increases as the electrolyte concentration increases. As the electrolyte concentration increases the negative and positive charges, which responsible to transfer the electrical current increases, leading to increase the MRR. It is obvious that the effect of the electrolyte concentration at $0 \mathrm{~mm}$ depth of cut is better than that of at $0.1 \mathrm{~mm}$. This is may be due to decreasing the chance of the electrochemical action to take place at $0.1 \mathrm{~mm}$ depth of cut, where the mechanical action is increased by increasing the depth of cut. The results show that the MRR improves as the electrolyte concentration increases from $10 \mathrm{wt} . \%$ to $20 \mathrm{wt} . \% \mathrm{NaCl}$ at $0 \mathrm{~mm}$ depth of cut from 2.733 to $4.256 \mathrm{~mm}$ at $\mathrm{f}=6.81 \mathrm{Ipm}$ feed rate and from 3.627 to $5.894 \mathrm{~g} / \mathrm{min}$ at $27.44 \mathrm{Ipm}$ feed rate. Whereas, at $0.1 \mathrm{~mm}$ depth of cut it improves from 3.572 to $4.576 \mathrm{~g} / \mathrm{min}$ at $\mathrm{f}=6.81 \mathrm{Ipm}$ feed rate and from 6.278 to $6.903 \mathrm{~g} / \mathrm{min}$ at $27.44 \mathrm{Ipm}$ feed rate. On the other hand the MRR increases as the depth of cut increases from 0 to $0.1 \mathrm{~mm}$. 


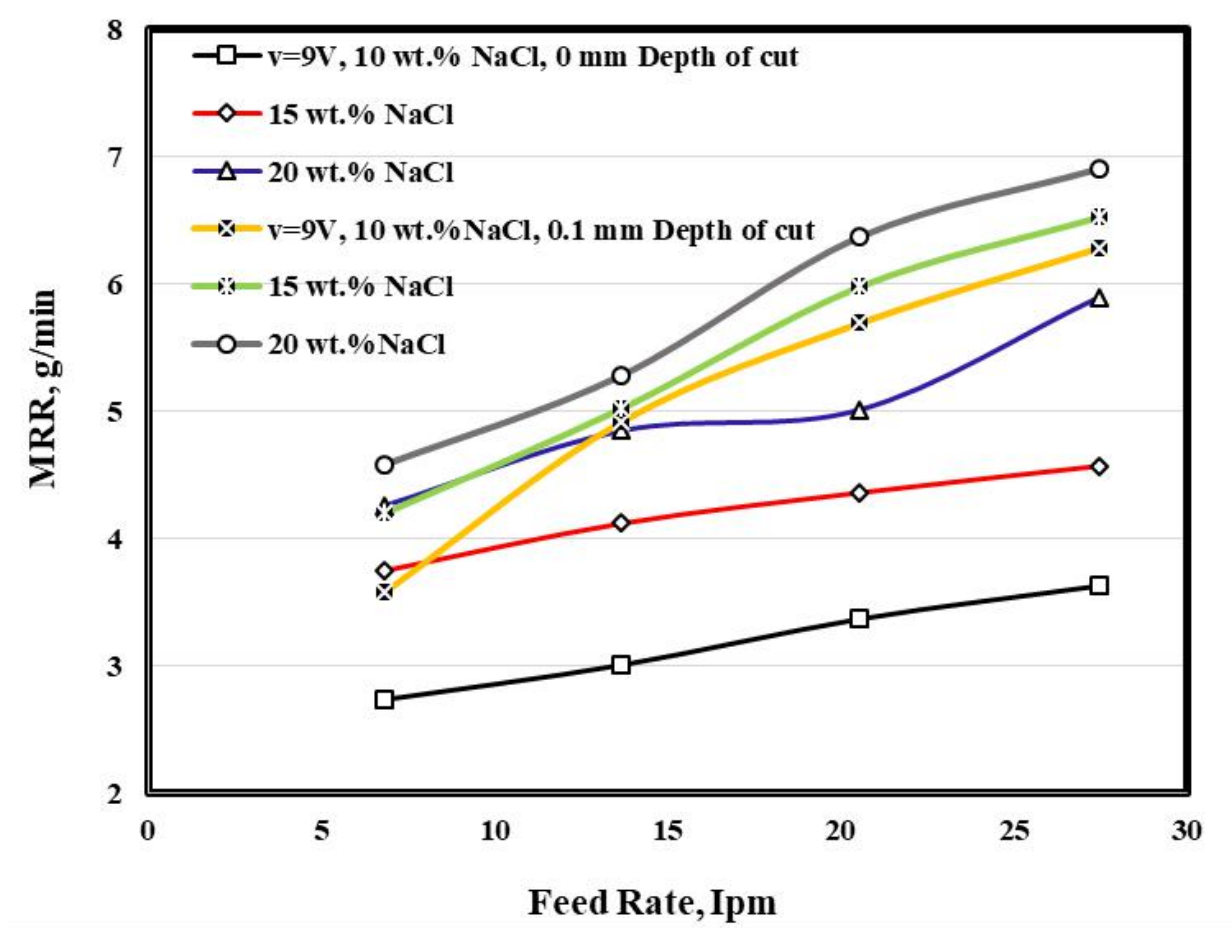

Fig. (4) Variations of metal removal rate $(\mathrm{g} / \mathrm{min})$ with the feed rate at different depths of cut, different electrolyte concentrations and at voltage $\mathrm{v}=9 \mathrm{~V}$

Figure 5 illustrates the same relation between the feed rate and the metal removal rate at different depth of cut and different electrolyte concentration, but at voltage $\mathrm{v}=11.5 \mathrm{~V}$. It is evident form the results that the effect of the feed rat on the metal removal rate at $\mathrm{v}=11.5 \mathrm{~V}$ takes the same trend of the results at $\mathrm{v}=9 \mathrm{~V}$ as shown in figure 4 . Where, the metal removal rate increases by increasing the feed rate and the effect of the electrolyte concentration at $0 \mathrm{~mm}$ depth of cut is better than the effect of it at $0.1 \mathrm{~mm}$ depth of cut. The effect of the electrolyte concentration at $0.1 \mathrm{~mm}$ depth of cut is improved as compared with the MRR at $\mathrm{v}=9$ $\mathrm{V}$, and this is may be due to increasing the electrochemical action as a result of increasing the voltage from 9 to $11.5 \mathrm{~V}$. At voltage $9 \mathrm{~V}$, the MRR improved from 3.572 to $4.576 \mathrm{~g} / \mathrm{min}$ at $\mathrm{f}=6.81 \mathrm{Ipm}$ feed rate and from 6.278 to $6.903 \mathrm{~g} / \mathrm{min}$ at $\mathrm{f}=$ $27.44 \mathrm{Ipm}$ feed rate as shown in figure 4. Whereas, it increases from 5.332 to 6.816 $\mathrm{g} / \mathrm{min}$ at $\mathrm{f}=6.81 \mathrm{Ipm}$ and from 7.896 to $8.754 \mathrm{~g} / \mathrm{min}$ at $27.44 \mathrm{Ipm}$. 


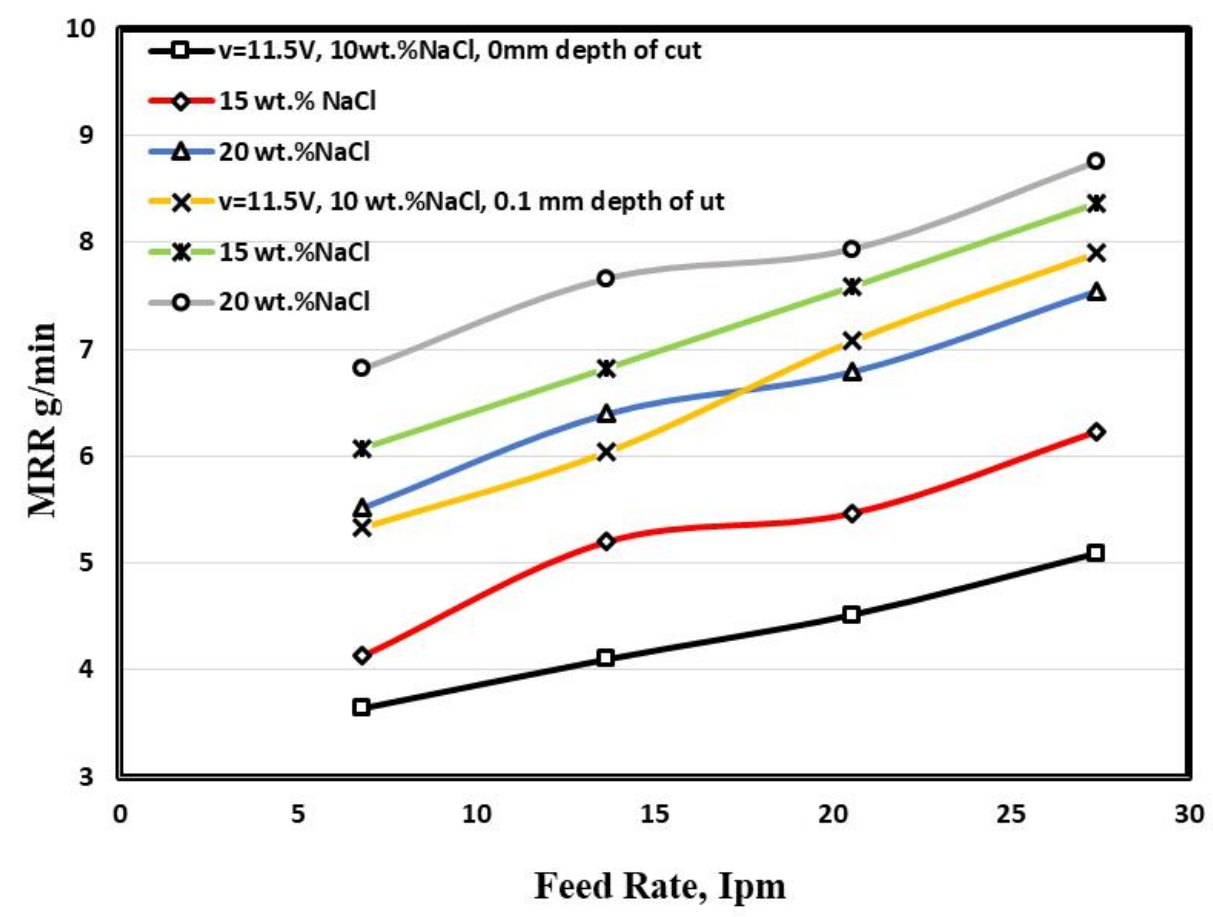

Fig. (5) Variations of metal removal rate $(\mathrm{g} / \mathrm{min})$ with the feed rate at different depths of cut, different electrolyte concentrations, and at voltage $\mathrm{v}=11.5 \mathrm{~V}$

\subsection{Metal Removal Rate of the Abrasive Electrochemical Grinding Process (AECG) at voltage $v=9 \mathrm{~V}$}

Figure 6 ( $a, b, c$ and $d)$ shows the effect of $\mathrm{Al}_{2} \mathrm{O}_{3}$ abrasive concentrations on the MRR of the ECG process at a different depths of cut and different electrolyte salt concentrations. All The experiments were performed at a voltage $\mathrm{v}=9 \mathrm{~V}$. The figures from (a) to (d), show that the metal removal rate increases by increasing the $\mathrm{Al}_{2} \mathrm{O}_{3}$ abrasive concentration up to $5 \mathrm{wt}$. \% then decreases. They also show that the effect of the abrasive particles at $0 \mathrm{~mm}$ depth of cut is greater than the effect of it at 0.1 $\mathrm{mm}$ depth of cut. For example, at the lowest feed rate, figure (a) shows that the MRR at 10 wt. $\% \mathrm{NaCl}$ and $0 \mathrm{~mm} \mathrm{DOC}$ is increased from $2.733 \mathrm{~g} / \mathrm{min}$ (when no abrasive particles are applied) to $3.849 \mathrm{~g} / \mathrm{min}$ at $5 \mathrm{wt} . \% \mathrm{Al}_{2} \mathrm{O}_{3}$ (the difference in the MRR is $1.116 \mathrm{~g} / \mathrm{min}$ ). At the same conditions and at $0.1 \mathrm{~mm}$ the MRR is increased from $4.272 \mathrm{~g} / \mathrm{min}$ (when no abrasive particles were added) to $5.098 \mathrm{~g} / \mathrm{min}$ at $5 \mathrm{wt}$. $\% \mathrm{Al}_{2} \mathrm{O}_{3}$ (the difference in the MRR is $0.826 \mathrm{~g} / \mathrm{min}$ ). The results at $(15 \mathrm{wt} . \% \mathrm{NaCl}$ ) and $(20 \mathrm{wt} . \% \mathrm{NaCl})$ take the same trend. On the other hand, at the highest feed rate, figure (d) shows that the MRR at $10 \mathrm{wt} . \% \mathrm{NaCl}$ and $0 \mathrm{~mm} \mathrm{DOC}$ is increased from $3.627 \mathrm{~g} / \mathrm{min}$ (when no abrasive particles were added) to $4.708 \mathrm{~g} / \mathrm{min}$ at $5 \mathrm{wt} . \%_{\mathrm{Al}_{2} \mathrm{O}_{3}}$ (the difference in the MRR is $1.081 \mathrm{~g} / \mathrm{min}$ ). At the same conditions and at $0.1 \mathrm{~mm}$ the MRR is increased from $6.278 \mathrm{~g} / \mathrm{min}$ (when no abrasive particles were added) to $6.836 \mathrm{~g} / \mathrm{min}$ at $5 \mathrm{wt} . \% \mathrm{Al}_{2} \mathrm{O}_{3}$ (the difference in the MRR is $0.558 \mathrm{~g} / \mathrm{min}$ ). Also, the results at $(15 \mathrm{wt} . \% \mathrm{NaCl})$ and $(20 \mathrm{wt} . \% \mathrm{NaCl})$ take the same trend.

Regardless of increasing the MRR with increasing the electrolyte salt concentration of the electrochemical grinding process $(E C G)$, the results revealed that the best effect of the abrasive particles is at $10 \mathrm{wt} . \% \mathrm{NaCl}$. 
From the explained results, it can be concluded that the best conditions to achieve the highest MRR are 10 wt. $\% \mathrm{NaCl}, 5$ wt. $\% \mathrm{Al}_{2} \mathrm{O}_{3}$, and at the lowest feed rate $\mathrm{f}=6.81 \mathrm{Ipm}$. At these conditions, the metal removal rate is increased from 2.733 $\mathrm{g} / \mathrm{min}$ (when no abrasive particles are added) to $3.849 \mathrm{~g} / \mathrm{min}$ (when $5 \mathrm{wt} . \% \mathrm{Al}_{2} \mathrm{O}_{3}$ abrasive particles are added) with improvement percentage $40.8 \%$.

The gap between the grinding wheel and the work-piece at $0 \mathrm{~mm}$ depth of cut is greater than the gap between them at $0.1 \mathrm{~mm}$ depth of cut and this gives the grinding wheel the chance to strike the particles in the direction of the work-piece surface. As a result of hammering the abrasive particles by the grinding wheel, they acquire high velocity and subsequently high Kinetic energy. Striking the surface of the work-piece with high force make the particles erode the surface and aids in removing the precipitates which are formed during the electrochemical reaction, leading to cracking and fracture of the work-piece surface, resulting into increasing the metal removal rate.

Lowering the effect of the abrasive particles at $0.1 \mathrm{~mm}$ depth of cut may be related to the number of particles which can be embedded in the machining zone and share in the cutting during the machining process. At $0.1 \mathrm{~mm}$ depth of cut, the gap becomes minimum and may lead to restrict the particles motion in the machining zone, leading to decrease in the MRR.

The results also manifest that the effect of the abrasive particles is decreased by increasing the electrolyte concentration and this may be related to increasing the oxide passive layer which produced as a result of the electrochemical reaction during the machining process. As the electrolyte concentration increases, the electrical current and deposited layer increase. Oxide deposited layer disengage and consumes a part of kinetic energy of the abrasive particles and leads to a decrease in the performance of it, leading to decrease the effect of it on the metal removal rate.

Furthermore, the results show that the effect of the abrasive particles decreases as the feed rate increases. Increasing the feed rate leads to reducing the time of machining process, so that the effective time of the particles decreases, which finally leads to decrease in the MRR of the AECG by increasing the feed rate.

Decreasing the effect of the abrasive particles after 5 wt. $\% \mathrm{Al}_{2} \mathrm{O}_{3}$ may be due to decreasing the efficiency of the electrochemical reaction. At 7.5 wt. $\% \mathrm{Al}_{2} \mathrm{O}_{3}$, the experiments showed that the abrasive hiders the current to pass with high efficiency, leading to decrease the MRR of the ECG. 

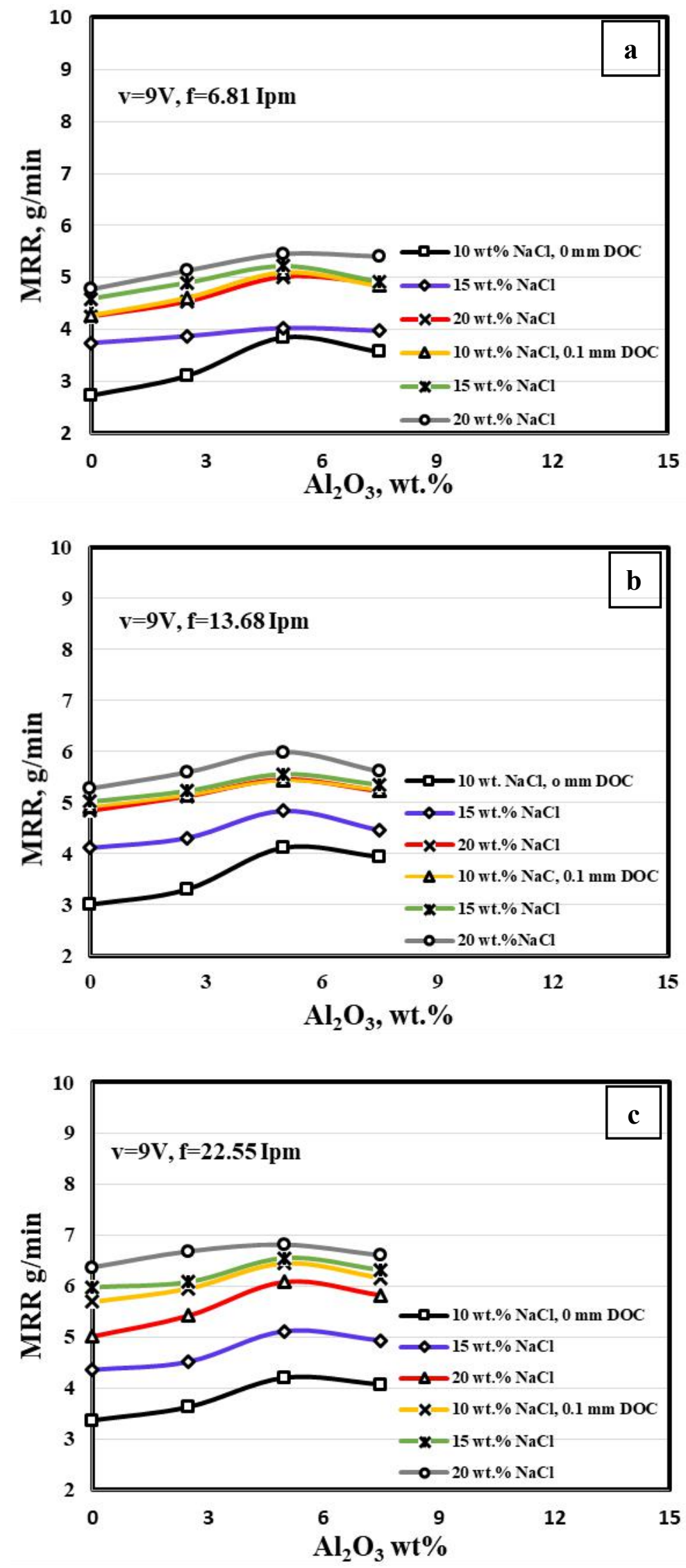


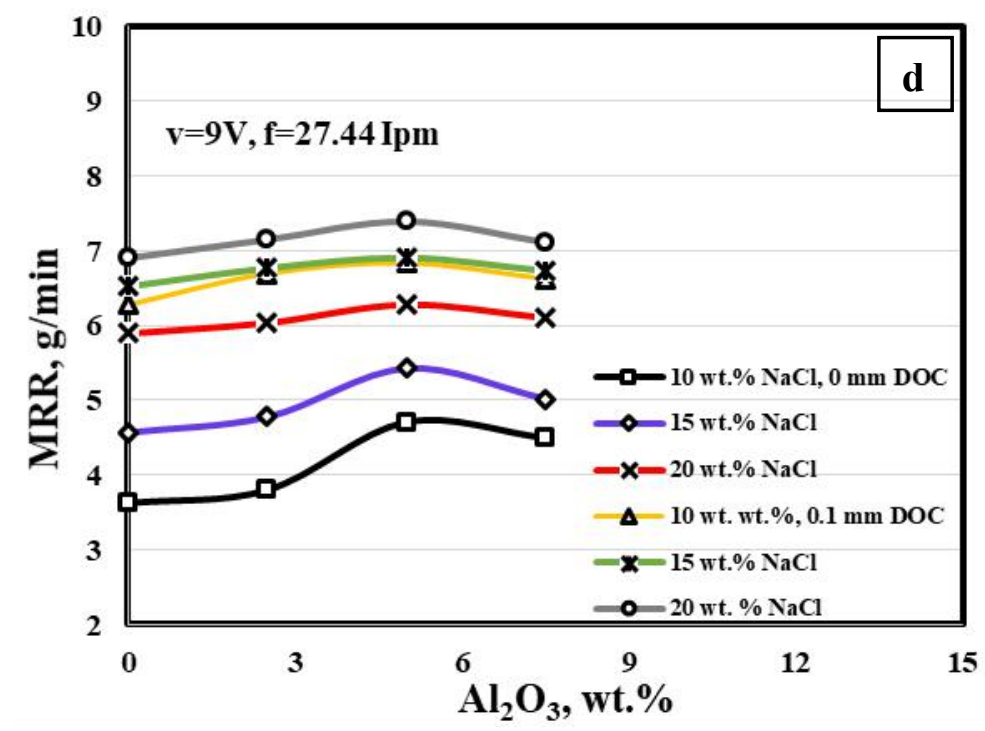

Fig. 6 Variation of metal removal rate $(\mathrm{g} / \mathrm{min})$ of the $\mathrm{ECG}$ with $\mathrm{Al}_{2} \mathrm{O}_{3}$ wt. \% concentration at different electrolyte concentrations, different depths of cut, voltage $\mathrm{v}=9 \mathrm{~V}$ and feed rates (a) f=6.81 Ipm, (b) f=13.68 Ipm, (c) f=22.55 Ipm and (d) f=27.44 Ipm

\subsection{Metal Removal Rate of the Abrasive Electrochemical Grinding Process (AECG)}

at voltage $=11.5 \mathrm{~V}$

Figure 7 (a, b, c, and d) illustrates the effect of $\mathrm{Al}_{2} \mathrm{O}_{3}$ wt. \% abrasive powder concentrations, electrolyte concentrations and depths of cut on the MRR of the ECG at voltage $v=11.5 \mathrm{~V}$. It is obvious from all figures (a to d) that the MRR increases by increasing the weight percentage of the $\mathrm{Al}_{2} \mathrm{O}_{3}$ abrasive powder up to $5 \mathrm{wt}$. \%. In addition, the results show that the effect of the abrasive assist particles on the MRR of the ECG at $0 \mathrm{~mm}$ depth of cut is stronger than its effect on the MRR at $0.1 \mathrm{~mm}$ depth of cut, which is the same effect at voltage $\mathrm{v}=9 \mathrm{~V}$. Also, they show that the effect of the $\mathrm{Al}_{2} \mathrm{O}_{3}$ on the MRR is decreased by increasing the electrolyte concentration.

The strongest effect of the $\mathrm{Al}_{2} \mathrm{O}_{3}$ at $\mathrm{v}=11.5 \mathrm{~V}$ is at $\mathrm{f}=22.55 \mathrm{Ipm}, 10$ wt. $\% \mathrm{NaCl}$ and at $0 \mathrm{~mm}$ DOC. Where the MRR before adding $\mathrm{Al}_{2} \mathrm{O}_{3}$ is $4.515 \mathrm{~g} / \mathrm{min}$ and after adding $\mathrm{Al}_{2} \mathrm{O}_{3}$ is 5.559 at 5 wt. $\% \mathrm{Al}_{2} \mathrm{O}_{3}$. The MRR of the ECG is improved with percentage $23.1 \%$.

Comparing the results of the MRR at $\mathrm{v}=9 \mathrm{~V}$ with its results at $\mathrm{v}=11.5 \mathrm{~V}$, it can be concluded that the effect of the $\mathrm{Al}_{2} \mathrm{O}_{3}$ at $\mathrm{v}=9 \mathrm{~V}$ is stronger the effect of it at $\mathrm{v}=11.5$ $\mathrm{V}$. At $\mathrm{v}=9 \mathrm{~V}$ (figure a) the difference in the MRR before and after adding the $\mathrm{Al}_{2} \mathrm{O}_{3}$ at 10 wt. $\% \mathrm{NaCl}$ is $1.116 \mathrm{~g} / \mathrm{min}$ at $0 \mathrm{~mm} \mathrm{DOC}$ and is $0.826 \mathrm{~g} / \mathrm{min}$ at $0.1 \mathrm{~mm} \mathrm{DOC}$, Whereas at $\mathrm{v}=11.5 \mathrm{~V}$ the difference in the MRR before and after adding the $\mathrm{Al}_{2} \mathrm{O}_{3}$ at 10 wt. $\% \mathrm{NaCl}$, is $1.044 \mathrm{~g} / \mathrm{min}$ at $0 \mathrm{~mm} \mathrm{DOC}$ and is $0.812 \mathrm{~g} / \mathrm{min}$ at $0.1 \mathrm{~mm} \mathrm{DOC}$.

Decreasing the effect of $\mathrm{Al}_{2} \mathrm{O}_{3}$ particle powder at $\mathrm{v}=11.5 \mathrm{~V}$ may be due to increasing the passive layer as a result of increasing the voltage from $9 \mathrm{~V}$ to $11.5 \mathrm{~V}$. Passive layer consumes some value of kinetic energy of the particles that produced from striking it with the grinding wheel, which leads to decreasing the efficiency of it. 

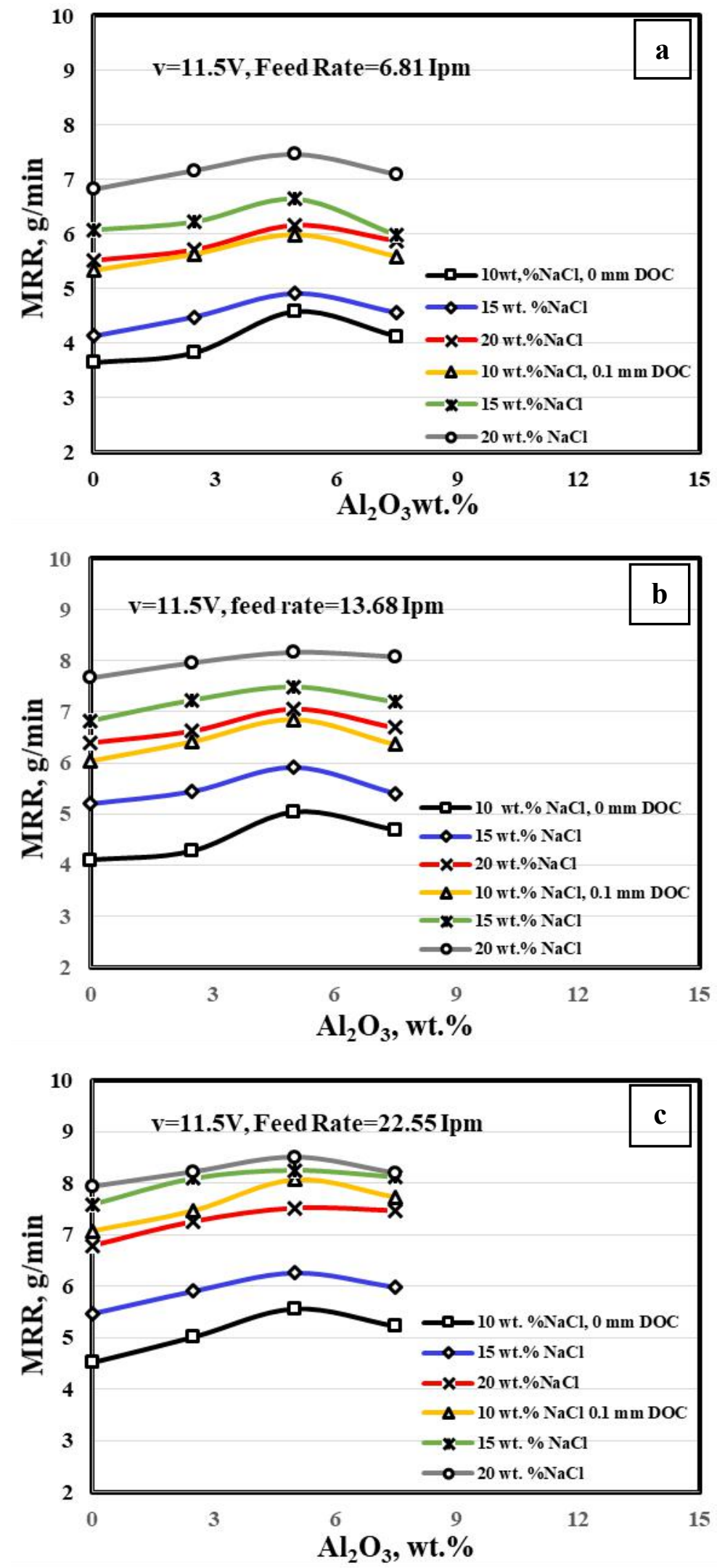


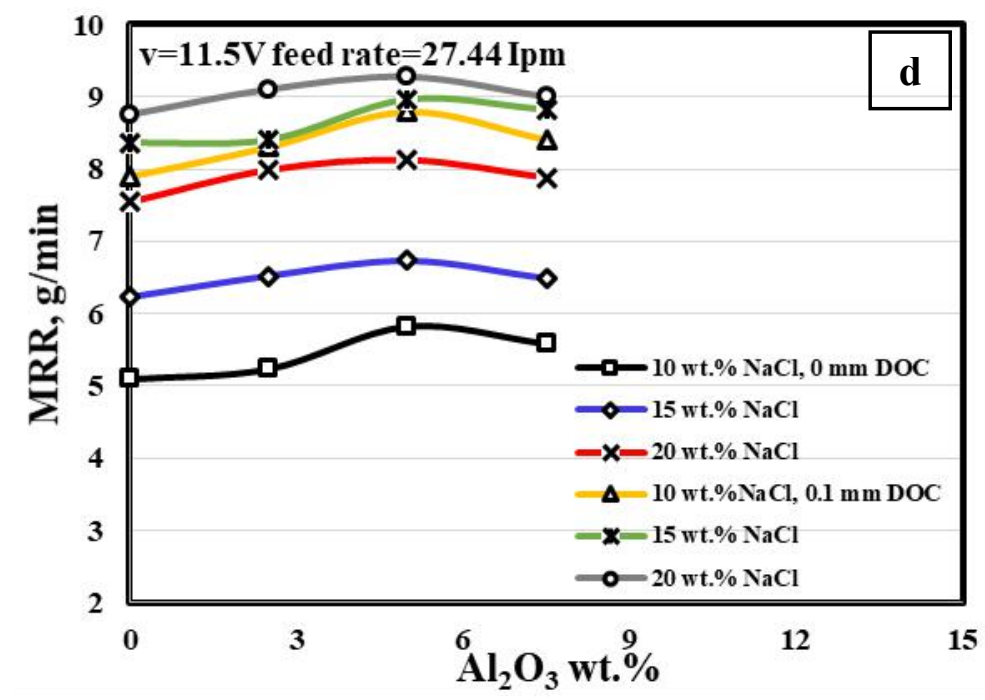

Fig. 7 Variations of the metal removal rate $(\mathrm{g} / \mathrm{min})$ of the $\mathrm{ECG}$ with $\mathrm{Al}_{2} \mathrm{O}_{3}$ wt. \% concentration at different electrolyte concentrations, different depths of cut (DOC), voltage $\mathrm{v}=11.5 \mathrm{~V}$ and feed rates (a) $\mathrm{f}=6.81 \mathrm{Ipm}$, (b) $\mathrm{f}=13.68 \mathrm{Ipm}$, (c) $\mathrm{f}=22.55 \mathrm{Ipm}$ and (d) $\mathrm{f}=27.44$ $\mathrm{Ipm}$

\subsection{Effect of the $\mathrm{Al}_{2} \mathrm{O}_{3}$ wt. \% on the electrical current of the ECG}

The experimental results of the electrical current of the abrasive assisted ECG of K110 alloy steel are presented in Table 3. It is obvious from the table that the current increases by increasing the electrolyte concentration and the feed rate. On the other hand, the electrical current is affected by the abrasive concentration, where it is beginning to be decreased after 5 wt. $\% \mathrm{Al}_{2} \mathrm{O}_{3}$ addition. $\mathrm{Al}_{2} \mathrm{O}_{3}$ ceramic material is a non-conductive material and the presence of it in the electrolyte of the ECG process at a percentage over than $5 \mathrm{wt} \%$ hinders the motion of the ions which leads to a decrease in the current to pass during the electrochemical reaction, leading to a decrease in the metal removal rate of the AECG. 
Table 3: Experimental results of the electrical current of A-ECG

\begin{tabular}{|c|c|c|c|c|c|c|c|}
\hline \multicolumn{2}{|c|}{ Depth of cut } & \multicolumn{3}{|c|}{$0 \mathrm{~mm}$} & \multicolumn{3}{|c|}{$0.1 \mathrm{~mm}$} \\
\hline \multirow[t]{2}{*}{ Fixed para. } & $\mathrm{NaCl}$ Wt. & \multirow[t]{2}{*}{10} & \multirow[t]{2}{*}{15} & \multirow[t]{2}{*}{20} & \multirow[t]{2}{*}{10} & \multirow[t]{2}{*}{15} & \multirow[t]{2}{*}{20} \\
\hline & Al2O3 wt. & & & & & & \\
\hline \multirow{4}{*}{$\begin{array}{c}\mathrm{v}=9 \mathrm{~V} \\
\mathrm{f}=6.81 \mathrm{Ipm}\end{array}$} & 0 & 95 & 105 & 115 & 105 & 115 & 125 \\
\hline & 2.5 & 95 & 110 & 120 & 100 & 120 & 130 \\
\hline & 5 & 90 & 105 & 115 & 105 & 115 & 125 \\
\hline & 7.5 & 75 & 95 & 105 & 90 & 100 & 115 \\
\hline \multirow{4}{*}{$\begin{array}{c}\mathrm{v}=9 \mathrm{~V} \\
\mathrm{f}=13.81 \mathrm{Ipm}\end{array}$} & 0 & 100 & 110 & 125 & 125 & 120 & 140 \\
\hline & 2.5 & 95 & 110 & 125 & 125 & 120 & 140 \\
\hline & 5 & 95 & 110 & 125 & 125 & 120 & 140 \\
\hline & 7.5 & 80 & 100 & 110 & 105 & 110 & 125 \\
\hline \multirow{4}{*}{ 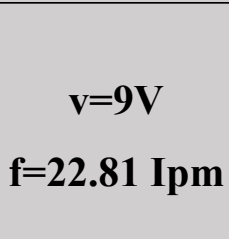 } & 0 & 105 & 120 & 145 & 135 & 135 & 160 \\
\hline & 2.5 & 100 & 115 & 150 & 130 & 130 & 155 \\
\hline & 5 & 105 & 120 & 145 & 125 & 125 & 150 \\
\hline & 7.5 & 90 & 105 & 120 & 110 & 110 & 135 \\
\hline \multirow{4}{*}{$\begin{array}{c}\mathrm{v}=9 \mathrm{~V} \\
\mathbf{f}=\mathbf{2 7 . 4 4} \mathrm{Ipm}\end{array}$} & 0 & 110 & 125 & 155 & 145 & 150 & 190 \\
\hline & 2.5 & 115 & 125 & 150 & 145 & 150 & 190 \\
\hline & 5 & 110 & 125 & 150 & 145 & 155 & 185 \\
\hline & 7.5 & 95 & 110 & 125 & 125 & 135 & 160 \\
\hline \multirow{4}{*}{$\begin{array}{c}v=11.5 \mathrm{~V} \\
f=6.81 \mathrm{Ipm}\end{array}$} & 0 & 130 & 130 & 160 & 160 & 150 & 185 \\
\hline & 2.5 & 125 & 130 & 165 & 155 & 155 & 190 \\
\hline & 5 & 125 & 135 & 160 & 160 & 150 & 190 \\
\hline & 7.5 & 105 & 120 & 145 & 140 & 140 & 170 \\
\hline \multirow{4}{*}{$\begin{array}{c}\mathrm{v}=11.5 \mathrm{~V} \\
\mathrm{f}=13.81 \mathrm{Ipm}\end{array}$} & 0 & 135 & 140 & 175 & 160 & 175 & 210 \\
\hline & 2.5 & 135 & 145 & 170 & 165 & 180 & 210 \\
\hline & 5 & 130 & 145 & 175 & 165 & 175 & 205 \\
\hline & 7.5 & 110 & 120 & 155 & 155 & 150 & 190 \\
\hline \multirow{4}{*}{$\begin{array}{c}\mathrm{v}=11.5 \mathrm{~V} \\
\mathrm{f}=22.81 \mathrm{Ipm}\end{array}$} & 0 & 150 & 160 & 200 & 185 & 190 & 225 \\
\hline & 2.5 & 150 & 155 & 205 & 180 & 185 & 220 \\
\hline & 5 & 160 & 150 & 200 & 175 & 185 & 220 \\
\hline & 7.5 & 140 & 135 & 175 & 160 & 165 & 210 \\
\hline \multirow{4}{*}{$\begin{array}{c}v=11.5 \mathrm{~V} \\
f=27.44 \mathrm{Ipm}\end{array}$} & 0 & 160 & 165 & 210 & 200 & 205 & 245 \\
\hline & 2.5 & 155 & 165 & 210 & 205 & 210 & 240 \\
\hline & 5 & 160 & 165 & 205 & 200 & 215 & 235 \\
\hline & 7.5 & 145 & 150 & 190 & 190 & 190 & 210 \\
\hline
\end{tabular}




\section{Conclusion}

In the present experimental investigation of the alloy steel K110, the effect of the $\mathrm{Al}_{2} \mathrm{O}_{3}$ wt. $\%$ abrasive particles on the MRR of the ECG was studied. It was observed from the analysis of the experimental results that the MRR increases by increasing the abrasive particles concentration up to $5 \mathrm{wt} . \%$ then decreases at 7.5 wt. $\% \mathrm{Al}_{2} \mathrm{O}_{3}$. At voltage $\mathrm{v}=9 \mathrm{~V}$, the best effect of the $\mathrm{Al}_{2} \mathrm{O}_{3}$ wt. $\%$ was at $\mathrm{f}=6.81 \mathrm{Ipm}$ and 10 wt. $\% \mathrm{NaCl}$, where the MRR is improved with a percentage of $40.8 \%$. Whereas, at voltage $\mathrm{v}=11.5 \mathrm{~V}$ the best effect of the $\mathrm{Al}_{2} \mathrm{O}_{3}$ wt. $\%$ was at $\mathrm{f}=22.22 \mathrm{Ipm}$ and electrolyte concentration 10 wt. $\% \mathrm{NaCl}$, where the MRR is improved with a percentage of $23.1 \%$. Moreover, the presence of the $\mathrm{Al}_{2} \mathrm{O}_{3}$ in the electrolyte with a percentage over than $5 \mathrm{wt}$. \% leads to decrease its ability to transfer the electrical current, which affects the electrochemical reaction and consequently the metal removal rate of the abrasive electrochemical grinding process.

\section{References}

1- R. N. Goswami, S. Mitra, S. Sarkar, Experimental investigation on electrochemical grinding (ECG) of alumina-aluminum interpenetrating phase composite, Int. J. Adv. Manuf. Technol., 40, (2009), 729-741

2- K. Rajkumar, L. Poovazhagan, P. Sarav., S J. S. Ibrahim, S Santosh, Abrasive Assisted Electrochemical Machining of Al-B 4 C Nano-composite, Applied Mechanics and Materials, 787, (2015), 523-527

3- N. S. Qu, Zhang Q.L, X. L. Fang, E. K. Ye, D. Zhu, Experimental Investigation on Electrochemical Grinding of Inconel 718, 15th Machining Innovations Conference for Aerospace Industr, Procedia CIRP, 35, ( 2015 ), 16-19

4- S. das, B. Doloi, B. Bhattacharyya, Experimental Investigation of Ultrasonic Machining on Alumina Bio-Ceramic for Stepped Hole Fabrication, 5th International \& 26th All India Manufacturing Technology, Design and Research Conference, IIT Guwahati, Assam, India, 12th-14th December 2014, (204-1)-(2047)

5- Abolkassem S. A., Omayma. A. Elkady, A. H. Elsayed, W. A. Hussein, H. M. Yehia, Effect of consolidation techniques on the properties of Al matrix composite reinforced with nano Ni-coated SiC, Result in physics, 2018, 9: 1102-1111.

6- H. M. Yehia, Microstructure, physical and mechanical properties of the $\mathrm{Cu} / \mathrm{WC}$ TiC-Co) nano-composites by the electro-less coating and powder metallurgy technique, Journal of Composite Materials, 11(2018) 1-9.

7- O. El-Kady, H. M. Yehia, F. Nouh, Preparation and characterization of $\mathrm{Cu} /(\mathrm{WC}-$ TiC-Co)/graphene nanocomposites as a suitable material for heat sink by powder metallurgy method, International Journal of Refractory Metals \& Hard Materials 79 (2019) 108-114.

8- H. El-Hofy, Advanced Machining Processes, McGraw-Hill Companies, 2005, Pp. 21

9- R. B. Heimann, Classic and Advanced Ceramics From Fundamentals to Applications, first ed. Wiley-Vch Verlag GmbH \& Co., Weinheim, 2010. 